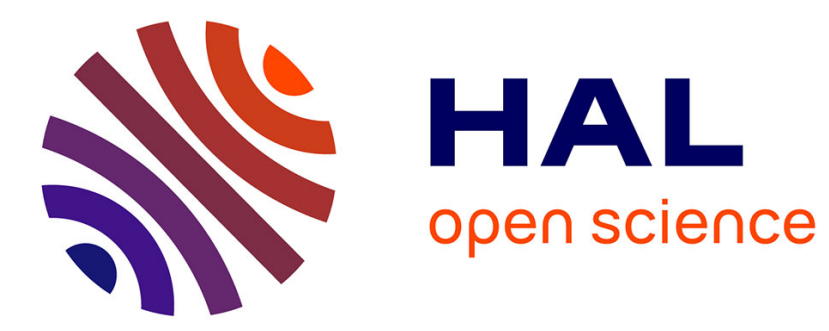

\title{
Anisotropic oxidation of circular mesas for complex confinement in photonic devices: Experiments and modelling
}

\author{
Gael Lafleur, Guilhem Almuneau, Stéphane Calvez, Henri Camon
}

\section{> To cite this version:}

Gael Lafleur, Guilhem Almuneau, Stéphane Calvez, Henri Camon. Anisotropic oxidation of circular mesas for complex confinement in photonic devices: Experiments and modelling. 19th International Conference on Transparent Optical Networks (ICTON 2017), Jul 2017, Girone, Spain. pp.1 - 1, 2017, 10.1109/ICTON.2017.8025118 . hal-01610908

\section{HAL Id: hal-01610908 \\ https: / hal.laas.fr/hal-01610908}

Submitted on 11 Oct 2017

HAL is a multi-disciplinary open access archive for the deposit and dissemination of scientific research documents, whether they are published or not. The documents may come from teaching and research institutions in France or abroad, or from public or private research centers.
L'archive ouverte pluridisciplinaire HAL, est destinée au dépôt et à la diffusion de documents scientifiques de niveau recherche, publiés ou non, émanant des établissements d'enseignement et de recherche français ou étrangers, des laboratoires publics ou privés. 


\title{
Anisotropic oxidation of circular mesas for complex confinement in photonic devices: experiments and modelling
}

\author{
Gael Lafleur, Guilhem Almuneau, Stéphane Calvez, Henri Camon \\ LAAS - CNRS, Université de Toulouse, CNRS, F-31400 France
}

In many different AlGaAs-based photonic and optical devices, the selective oxidation of an Al-rich layer is a very efficient way to create a lateral electrical and optical confinement. The degree of lateral confinement can thus be adjusted with the depth of the oxide within the structure. It is then of primary importance to control the lateral spreading of the oxidation reaction and that in all the crystallographic directions in order to master the waveguide properties in the 3 directions. Thanks to the epitaxial structure the vertical confinement can be designed with the index profile of the epitaxial multilayers, but in the lateral directions (in the plane of the epilayers) only the kinetics of the selective oxidation steers the waveguide dimensions.

The crystallographic anisotropy in the reaction of wet thermal oxidation of $\mathrm{Al}(\mathrm{Ga})$ As is well known since the discovery of this process in the early 1990s' [1-3]. As an example, in oxide confined VCSELs, the resulting asymmetric shape of the confinement aperture has a great impact on the properties of the output laser beam, positively as it may be a way to stabilize the polarization, or detrimentally as it modifies the transverse modes compared to a perfectly circular waveguide [4].

In this paper we propose to explore the process parameters that can act on the anisotropic character of the oxidation reaction.

[1] J. M. Dallesasse and N. Holonyak Jr. Appl. Phys. Lett. 58:4, 394-396 (1991)

[2] Floyd et al. Electron. Lett. 32114 (1996)

[3] K. D. Choquette et al., JSTQE 3, 916-926 (1997)

[4] P Debernardi et al, JQE 3873 (2002) 